保健物理, 10, 141 146（1975）

一般 論文

\title{
核分裂片飛跡のスパーク計数法による 熱中性子束密度の測定
}

森嶋彌重*1, 古賀妙子*1, 丹羽健夫*1, 本田嘉秀*2 河合 廣*1, 長野文彦*2, 西脇 安*3

(1975年 4 月 21 日受理)

Measurement of Thermal Neutron Flux by Means of Spark Counting Technique of Etched Nuclear Tracks

Hiroshige MoRishima, ${ }^{* 1}$ Taeko Koga, ${ }^{* 1}$ Takeo Niwa, ${ }^{* 1}$ Yoshihide Honda, ${ }^{* 2}$ Hiroshi KaWAI, ${ }^{* 1}$ Fumihiko NAGANO*2 and Yasushi NiShIWAKI*3

The measurements of thermal neutron flux were made by means of electrical spark counting technique of etched nuclear tracks on polycarbonate foils of $18 \mu \mathrm{m}$ thickness. By this method, spark counts of etch-pits below $400 / \mathrm{cm}^{2}$ on the foil can be counted within about $10 \%$ relative standard deviation and the minimum detectable limit of thermal neutron fluence was about $10^{5} / \mathrm{cm}^{2}$. The result of the thermal neutron distribution in a reactor (UTR-B) by electrical spark counting technique was in good agreement with that estimated by Au activation method within $6 \%$ deviation. The leakage of thermal neutron from the reactor operated at 0.1 watts for 3 hours was also determined to be 1.2 $\times 10^{6} / \mathrm{cm}^{2}$ (about $0.5 \mathrm{mrad} / 3 \mathrm{hr}$ ) by this method.

\section{I 緒論}

中性子線束あるいは中性子線量の測定法としては, 従 来いろいろな方法が利用されてきたが, 重荷電粒子であ る核分裂片の固体に対する放射線損傷の研究とエッチン グ法の利用により，いわゆる核分裂片による固体飛跡検 出法が大変有用であることが認められるようになっ た ${ }^{1 \sim 5)}$ 。固体飛跡検出器としては現在, 主としてガラス, 雲母およびプラスチックなどの絶縁性固体が用いられ， エッチングされたこれらの核分裂片飛跡の観察, 計数法

*1 近畿大学原子力研究所保健物理学研究室; 東大阪市小若 江 3-4-1 (宇577)

Lab. of Health Physics, Atomic Energy Research Institute, Kinki Univ.; 3-4-1, Kowakae, Higashi-Osaka-shi, Osaka-fu.

*2 近畿大学理工学部原子炉工学科; 東大阪市小若江 3-4-1 ( $\mathbf{T} 577$ )

Dept. of Nuclear Reactor Engineering, Faculty of Science and Technology, Kinki Univ.; 3-4-1, Kowakae, Higashi-Osaka-shi, Osaka-fu.

* 3 Div. of Health, Safety and Waste Management, International Atomic Energy Agency; Kaerntner Ring 11, Vienna, Austria.
としては，光学顕微鏡 ${ }^{1 \sim 6)}$ や投影法 ${ }^{7)}$ とともにレプリカ 法7) が用いられてきたが，これらの方法は多数の試料を 処理する場合には，時間がかかり，また疲労度も大きい ため, 検出用薄膜上の核分裂片飛跡のスパーク計数法が W.G. CROSS と L. TOMMASINO ${ }^{8)}$ により開発された。 この方法は，検出用薄膜を金属板電極とナイフェッジ電 極との間にはさみ電圧をかけ, 検出用薄膜上のエッチホ ールをナイフェッジ電極により走査して, 放電パルスの 計数を行なったものであるが, さらに高密度のエッチホ 一ルの計数と迅速化のために改良され, 両電極とも平面 として電圧をかけ，生じる放電パルスを計数した ${ }^{9212) 。 ~}$ そして, 核分裂物質と固体飛跡検出用薄膜の適当な組合 せにより，測定可能な中性子ェネルギーとその中性子線 束密度を変えることが可能となり, 中性子線量測定に適 用された。E.T. AGARD ら ${ }^{13)}$ は, 広い範囲のエネルギ 一域における中性子線量測定を検討 した。 S. PRETRE $ら^{14,15)}$ は，放射線管理のための中性子線量計として利用 の可能性を示した。スパーク計数法は，また核分裂片飛 跡のみならず, アルファ粒子飛跡計数にも応用されるこ とが報告され ${ }^{6,16 ~ 18)},(\mathrm{n}, \alpha)$ 反応やウラン鉱中のラドン 
およびその娘核種の個人被曝線量測定，さらに反跳反応 による速中性子测定などにも応用される。

欧米では, エッチホールのスパーク計数法が固体飛跡 計数法のもっとも簡便なものとして, 可搬型の装置が実 用化されているが，著者らは国産材料の $18 \mu \mathrm{m}$ 厚のポ リカーボネートを飛跡検出用薄膜とし, 核分裂物質ター ゲットとして, 天然ウランの組合せで近畿大学原子炉 UTR-B で中性子照射を行ない, 炉内熱中性子束密度测 定およびスパーク計数法について検討を行なった。

\section{II 実験}

1. 材料

核分裂片飛跡検出用薄膜としては $18 \mu \mathrm{m}$ 厚の帝人(侏) 製ポリカーボネートを，核分裂物質のターゲットとして ステンレス製板 $(\phi 3.3 \mathrm{~cm})$ に電着した天然ウランを用 いた。電着されたウラン量は， $2 \pi$ ガスフロー計数装置 (旧富士通製，GCS-1A)により，その $\alpha$ 放射 能を測定することにより算出し，格子付電離 箱（大阪電波製， GIC-I）による $\alpha$ 線エネル ギースペクトル測定により，ウラン以外の核 分裂物質の混在しないことを確認した。核分 裂物質ターゲットと飛跡検出器であるポリカ ーボネートを密着し，セロテープで固定して 照射試料とした。

\section{2. 中性子照射}

Fig. 1 に示した近畿大学原子炉UTR-Bの 中央黒鉛反射材上, 試料照射用ストリンガー （No.4）の照射孔 5 点および原子炉遮蔽タン ク上蓋の中央にある原子炉起動用中性子源挿

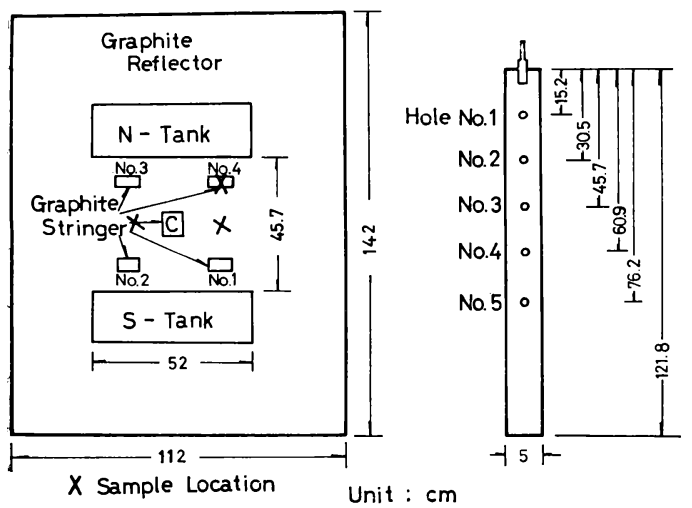

Horizontal View of UTR-B Sample Hole of Stringer

Fig. 1 Schematic representation of sample locations in reactor (UTR-B).
入孔付近に打いて, 熱出力 0.1 ワットで中性子照射を 30 分〜6 時間行なった。熱中性子束密度の較正は金䇴の放 射化法により行ない, 最高熱中性子束密度は $2 \times 10^{6} / \mathrm{cm}^{2}$. secであった。

\section{3. エッチング法}

中性子照射後, ポリカーボネートを $60^{\circ} \mathrm{C}$ の $30 \%$ 水 酸化カリウム溶液に 20 分間浸し, マグネチックスター ラーで䚌拌しながらェッチングを行なった。ポリカーボ ネートは流水で水洗の後, $60^{\circ} \mathrm{C}$ で乾燥しデシヶータ中 に保存した。

\section{4. 光学顕微鏡による観察}

オリンパス(侏製顕微鏡（ECE Tr-II），倍率 400 倍で, 薄膜上のエッチピットの計数を 30 視野について行なっ た。

\section{5. スパーク計数法 ${ }^{12)}$}

装置の検出部を Fig. 2 に示した。検出部の外装はべ

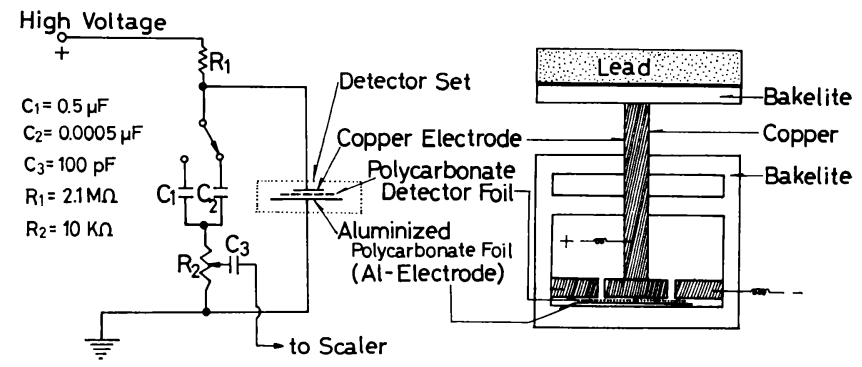

Circuit Diagram

Detector Set

Fig. 2 Circuit diagram and detector set of electrical spark counting.

一クライト製で，電極板は直径 $2.6 \mathrm{~cm}$ の銅製とし，飛 跡検出用ポリカーボネートに, もら一方の電極であるア ルミニウム蒸着のポリカーボネート（蒸着アルミニウム

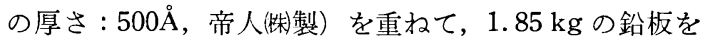
のせ，電極間にはさんだポリカーボネートに均一に圧力 がかかるようにして，スパーク放電が一様となるように し，Fig. 2 に示した回路でスパーク計数を行なった。 操作は，まず電圧 $1,400 \mathrm{~V}$ でスパークによるパンチング (コンデンサー容量： $0.5 \mu \mathrm{F}$ ) を行ない,つぎに小孔の できたポリカーボネートを新しいアルミニウム蒸着ポリ カーボネートに重ね，750V の低い電圧でスパーク（コ ンデンサー容量 : $\left.5 \times 10^{-4} \mu \mathrm{F}\right)$ を行ない, 通常の 1,000 進計数装置（富士電機製，SA-250）でスパークパルスを 計数した。 


\section{III 結果と考察}

\section{1. ポリカーボネートにおける核分裂片飛跡の計数法} について

(1) 光学顕微鏡に上る計数

絶縁固体中の重荷電粒子飛跡は $\mu \mathrm{m}$ 以下で，そのまま では電子顕微鏡でのみ観察できる大ささであるが，エッ チングにより拡大され，300 400 倍の光学顕微鏡で観 察計数でさるようになる。中性子照射による核分裂物質 ターゲットに打手分裂表面密度は, 中性子束密度 $\left(/ \mathrm{cm}^{2} \cdot \mathrm{sec}\right)$, 中性子照射時間 $(\mathrm{sec})$, 核分裂断面積 $\left(\mathrm{cm}^{2}\right)$, および核分裂物質の原子数密度 $\left(/ \mathrm{cm}^{2}\right)$ の積として求め られ，ターゲット中の核分裂核種が 1 種類であるとき は，次式で示される。

$$
F=\int_{0}^{E} \int_{0}^{t} W \frac{N}{A} \sigma(E) \phi(E, t) d t d E
$$

ここで, $F=$ 核分裂数表面密度 $\left(/ \mathrm{cm}^{2}\right)$

$W=$ ターゲット中の核分裂核種の表面濃度

$\left(\mathrm{g} / \mathrm{cm}^{2}\right)$

$N=$ アボガドロ数

$A=$ 核分裂核種の原子量

$\sigma(E)=$ ×ネルギー $E$ の中性子に対する核分裂 断面積 $\left(\mathrm{cm}^{2}\right)$

$\phi(E \cdot t)=$ エネルギーEの中性子束密度

$\left(/ \mathrm{cm}^{2} \cdot \mathrm{sec}\right)$

である。核分裂物質として天然ウランを用いた場合，照 射位置に打いては熱中性子による ${ }^{235} \mathrm{U}$ の核分裂以外の 核分裂数の寄与（速中性子による ${ }^{238} \mathrm{U}$ の核分裂など） は，全体の $3 \%$ をこえないと思われる。ターゲット中の 電着された核分裂核種は，非常に薄い膜（最大厚さ0.11 $\mu \mathrm{m}$ ）を成しており，その厚さは核分裂片の飛程（密度 $19.3 \mathrm{~g} / \mathrm{cm}^{2}$ の物質中で $\left.7.1 \sim 12.9 \mu \mathrm{m}^{19)}\right)$ 以下であり, 自 己吸収は無視できる。上式により計算で求めた核分裂数 の表面密度の理論値と, 倍率 400 倍の光学顕微鏡で計数 したェッチピット数との関係を Fig. 3 に示した。最小 自乗法により，y=1.03x-0.12 の直線関係が得られた が，検鏡法によるエッチピット計数において，検出用薄 膜単位面積 $\left(\mathrm{cm}^{2}\right)$ 当り 220 個, すなわち核分裂物質電 着面積 $\left(4.52 \mathrm{~cm}^{2}\right)$ 当り 1,000 個以上のエッチピットに 対しては約 $20 \%$ の相対標準偏差を，これより少ないエ ッチピット数の測定の場合には, 約 $30 \%$ の相対標準偏 差を示した。そして, ターゲット中の天然ウランの表面 濃度 $2.2 \sim 22 \mu \mathrm{g} / \mathrm{cm}^{2}$ に执いて，ポリカーボネートを検 出器とした場合, 飛跡検出の効率 $\varepsilon(\varepsilon=P / F, P$ : エッチ ピット表面密度, $F$ : 核分裂数表面密度) は $1.02 \pm 0.27$

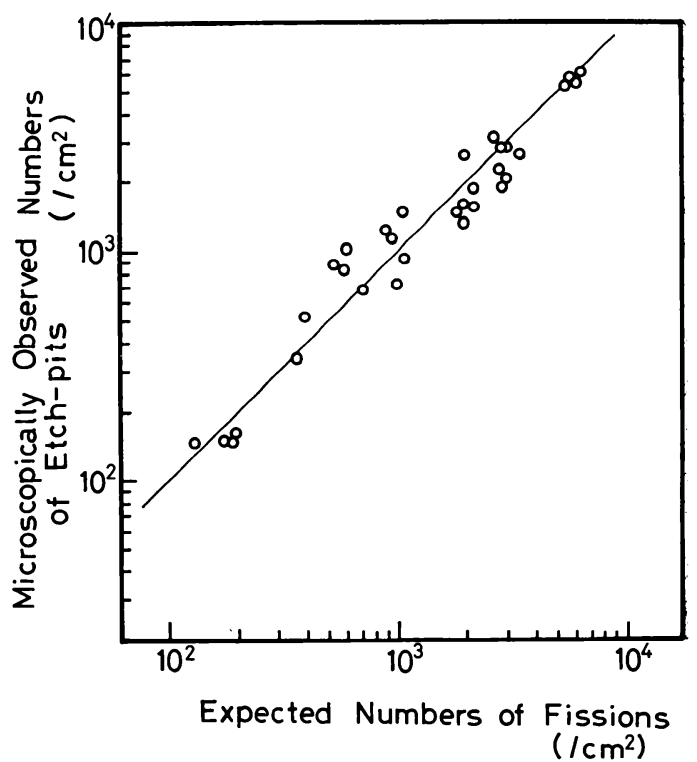

Fig. 3 Relation between microscopically observed numbers of etch-pits and expected numbers of fissions.

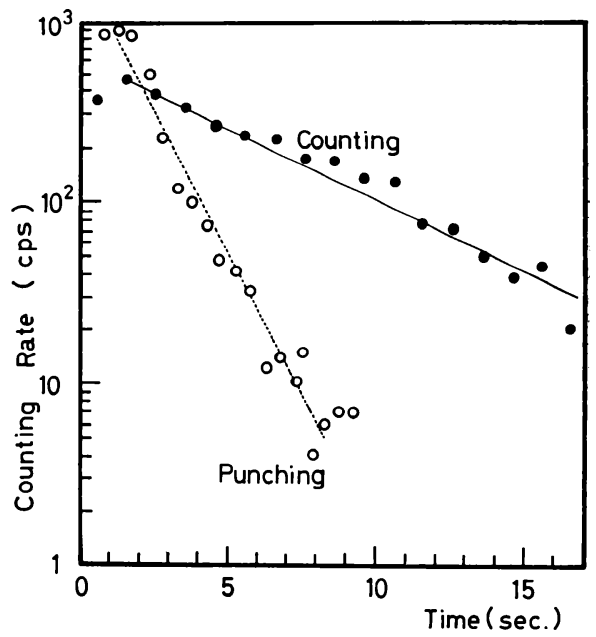

Fig. 4 Sparking rate decays.

が得られ，鶴田 ${ }^{4)}$ とよる雲母，ガラスと同様，飛跡検出 効率はほぼ 100\% であった。

（2）核分裂片飛跡のスパーク計数について

照射したポリカーボネートは，検鏡法の場合と同様に エッチングした後, 前記の方法でスパーク計数を行なっ た。パンチング電圧 $1,400 \mathrm{~V}$ ，カウンティング電圧 $750 \mathrm{~V}$ に拉けるそれそれれの計数率は，Fig.4 亿示したように 時間とともに指数関数的に減少したが，1,400V におけ るパンチング計数はほぼ数秒で終るため, そのスパーク 
パルスの計数には高速計数装置を用いても数え落しがあ り, 改めてょり低い電圧 $(750 \mathrm{~V})$ で再計数を行ならこと が必要である。両電極に電圧をかけた場合、コンデンサ 一に蓄えられた電気がエッチホールでスパークすると, 負電極となっている蒸着アルミニウムが蒸発する。つぎ に，充電によりコンデンサーの電圧が次第に上がり，つ ぎのエッチホールでスパークする。1 回スパークしたエ ッチホールの所は, 電極部分のアルミニウムが蒸発して いるので，同じェッチホールで 2 度スパーク寸る確率は 小さい。高密度エッチホールの検出用薄膜では，1つの エッチホールでスパークすると，スパークによって蒸発 したアルミニウムの孔 $(\phi 0.6 \sim 0.7 \mathrm{~mm})$ の面積中に含ま れる他のエッチホールでは，むはやスパークせず，数元 落しの原因となる。したがってスパーク計数值の上限は 蒸発アルミニウム孔の大きさが関係するが，著者らの実 験条件では約 $400 / \mathrm{cm}^{2}$ であった。E.T. AGARD ら ${ }^{13)}$ に よる結果では，検出用薄膜として $10 \mu \mathrm{m}$ う Makrofol G により，スパーク計数値の上限は約 $220 / \mathrm{cm}^{2}$ と報告し ているが, W.G. CROSS と L. TOMMASINO',10) による と, 同じ薄膜で $5,000 / \mathrm{cm}^{2}$ まで測定可能であるとしてい る。このスパークの際のアルミニウムの蒸発は, スパー ク計数の際のいろいろな条件に依存するが，特に電極に かけるべき最適のパンチングおよびカウンティング電压 は, アルミニウム蒸着薄膜のアルミニウムの厚さに依存 することが報告されている ${ }^{13)}$ 。アルミニウム蒸着膜厚 $500 \AA$ に打战るそれぞれの最適電圧は， $1,400 \mathrm{~V}$ および $750 \mathrm{~V}$ であった ${ }^{12)}$ 。

電着された核分裂物質の量より計算した核分裂数表面 密度と,スパーク計数法により測定したエッチホールの 数との関係を Fig. 5 に示した。これによると, スパー ク計数值が単位面積当り約 400 個までは計算值と比例関 係にあるが，単位面積当り 400 個以上になるとスパーク 数は飽和状態になり, 前述の蒸発したアルミニウム面積 より推定した計算值の上限値とほぼ一致している。直線 関係にある範囲のスパーク計数值に対しては, 相対標準 偏差 $10 \%$ 以内で計数可能である。

\section{2. 熱中性子フルエンスとスパーク計数值との関係}

ターゲット中の核分裂物質としてのウラン量を $10 \mu \mathrm{g}$ および $100 \mu \mathrm{g}$ につて (電着面積 $4.52 \mathrm{~cm}^{2}$ ), 照射熱 中性子フルェンス之検出用薄膜上に生じたエッチホール のスパーク計数值との関係を Fig. 6 に示した。ウラン $10 \mu \mathrm{g}$ では, 熱中性子フルェンス $10^{7} \sim 10^{10} / \mathrm{cm}^{2}$ の範囲 に扣いて,スパーク計数值との間に直線関係が得られた。 ウラン $100 \mu \mathrm{g}$ になると, 熱中性子フルェンスとスパー ク計数值との直線関係は, 熱中性子フルェンス, $3 \times 10^{9} \%$

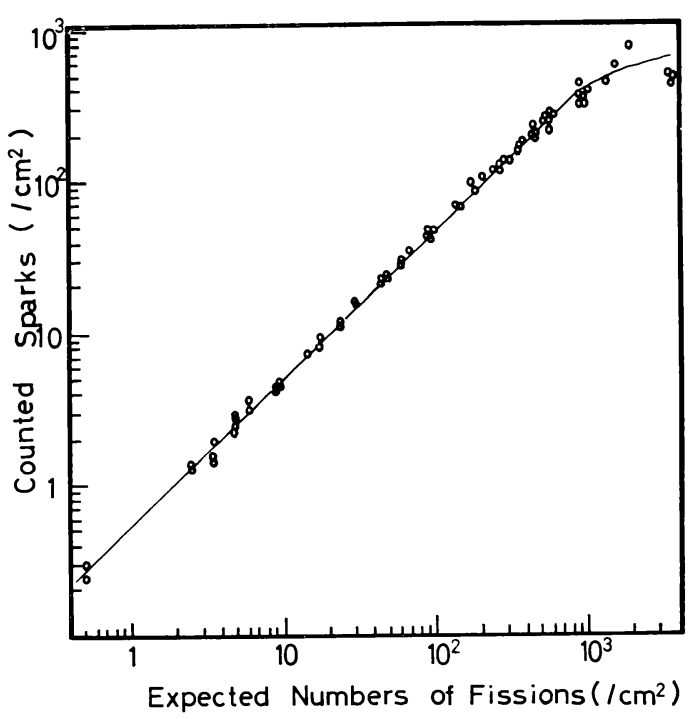

Fig. 5 Relation between counted sparks and expected numbers of fissions.

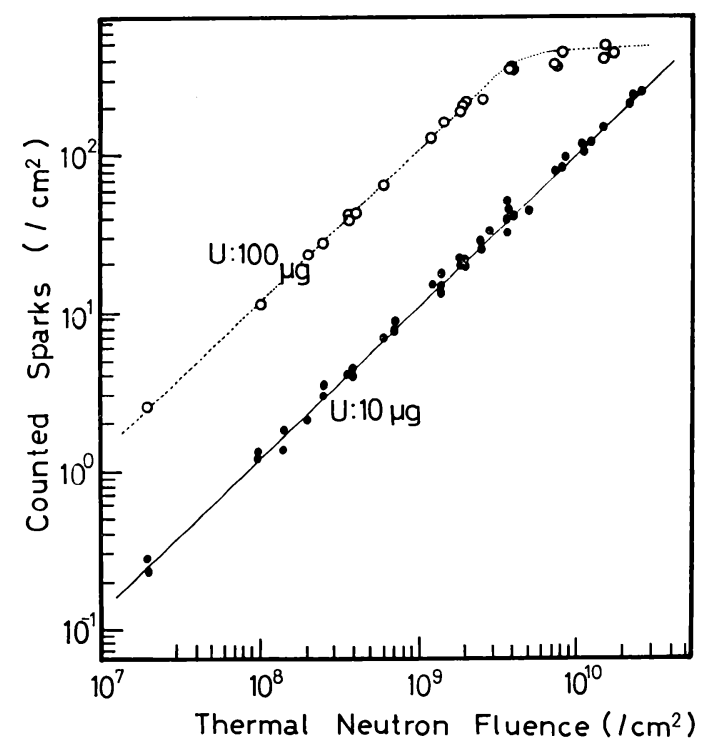

Fig. 6 Relation between counted sparks and thermal neutron fluence.

$\mathrm{cm}^{2}$ が上限となり，それ以上ではスパーク計数值は飽和 に達する。ターゲット中のウラン量と熱中性子フルェン スが直線関倸にある範囲を, Table 1 に示した。E.T. AGARD ら ${ }^{13)}$ によれば，核分裂物質を一定とした場合ス パーク計数值と中性子フルェンスの間の直線性は，スパ ーク計数の際の陰極となるアルミニウム蒸着膜が薄いほ ど広がると報告している。今回の実験では，アルミニウ 
Table 1 Measurable range of thermal neutron fluence using the spark counting method.

\begin{tabular}{ccc} 
Detector & $\begin{array}{c}\text { Range of } \\
\text { thermal } \\
\text { Insulating foil }\end{array}$ \\
\hline $\begin{array}{c}\text { Fissile material } \\
\text { natural } \\
\mathrm{U} / 4.52 \mathrm{~cm}^{2}\end{array}$ & $\begin{array}{c}\text { neutron fluence } \\
\left(/ \mathrm{cm}^{2}\right)\end{array}$ \\
\hline $\begin{array}{c}\text { Polycarbonate } \\
(18 \mu \mathrm{m})\end{array}$ & $10 \mu \mathrm{g}$ & $10^{7}-10^{10}$ \\
& $100 \mu \mathrm{g}$ & $10^{6}-10^{9}$ \\
& $1,000 \mu \mathrm{g}$ & $10^{5}-10^{8}$ \\
\hline
\end{tabular}

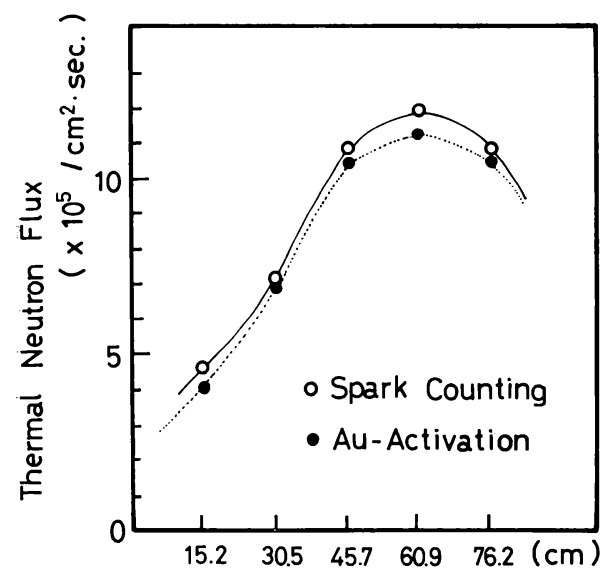

Distance from Top of Stringer

Fig. 7 Distribution of thermal neutron flux in No. 4 stringer of UTR-B.

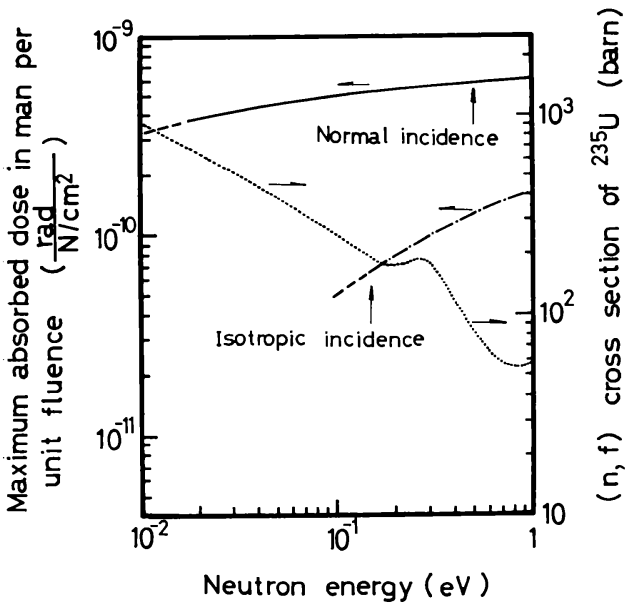

Fig. 8 Rad response of a pure ${ }^{235} \mathrm{U}$-detector between 0.012 and $0.17 \mathrm{eV}$.

么蒸着膜 $500 \AA$ のポリカーボネートのみにより実験を行 なったため, ウラン量を変化させることにより，スパー
ク計数値と熱中性子フルェンスとの間の直線性の範囲を 決定できた。低レベルの熱中性子フルェンスの測定には ウラン量として $1 \mathrm{mg}$ を使用して, 熱中性子フルェンス $10^{5} / \mathrm{cm}^{2}$ が測定可能となる。

3. スパーク計数法による炉内熱中性子束密度の測定 近畿大学原子炉 UTR-B の炉内熱中性子束密度を, 前 述のスパーク計数法および金䈃放射化分析法により測定 し，比較を行なった。核分裂物質(ターゲット)としては 電着ウラン試料 $10 \mu \mathrm{g}$ を使用し, UTR-B の照射用ストリ ンガーに拈ける熱中性子束密度分布を Fig. 7 に示した。 熱中性子束密度は, ストリンガーの上部より徐々に上昇 し，上端より約 $60 \mathrm{~cm}$ の位置にある照射孔 No. 4 に沶い て最も高く, $1.18 \times 10^{6} / \mathrm{cm}^{2} \cdot \sec$ (金䇴放射化法では $1.12 \times$ $\left.10^{6} / \mathrm{cm}^{2} \cdot \mathrm{sec}\right)$ となり，それ以下では減少した。両法によ る結果は, 約 $6 \%$ 以内で一致した。熱中性子束密度の非 常に低い場所として，原子炬遮蔽タンク上蓋上の原子炬 起動用中性子源挿入孔付近に拈ける 0.1 ワット，3 時間 原子炉運転中の漏洩熱中性子フルェンスをターゲットと して，ウラン量 $1 \mathrm{mg}$ を用いて測定した結果， $1.2 \times 10^{6} /$ $\mathrm{cm}^{2}$ であった。この值は, S. PRETRE の論文 ${ }^{14)} よ り$, 直角入射における熱中性子フルエンスの吸収線量への換 算図 (Fig. 8) から概算すると, 漏洩熱中性子吸収線量 は約 $0.5 \mathrm{mrad}$ となった。

\section{IV ま と め}

飛跡検出固体として $18 \mu \mathrm{m}$ 厚の帝人(侏製のポリカー ボネート，およびターゲットとして天然ウラン電着板を 用いた核分裂片飛跡のスパーク計数法により, 熱中性子 束密度の測定を検討した結果をまとめると，

1. 光学顕微鏡下での観測では計数が困難であると思 われるスパーク計数值約 $400 / \mathrm{cm}^{2}$ 以下のエッチピットの スパーク計数法による相対標準偏差は $10 \%$ 以下で， ス パーク計数のみに要する時間は 2 3 分間であり, 本法 は非常に有効である。

2. ターゲットとしての天然ウラン量 $(10 \mu \mathrm{g} \sim 1 \mathrm{mg})$ を変化させることによって, 熱中性子フルェンス $10^{5} \sim$ $10^{10} / \mathrm{cm}^{2}$ までスパーク計数法により測定可能であった。

3. 原子炉内熱中性子束分布の測定を, 核分裂片楸跡 のスパーク計数法と金䈃放射化分析法により比較した結 果, 約 $6 \%$ 以内で一致した。

4. 熱出力 0.1 ワットで 3 時間運転された原子炉から の漏洩熱中性子を本法で測定して，その中性子フルエン スは $1.2 \times 10^{6} / \mathrm{cm}^{2}$ (約 $0.5 \mathrm{mrad} / 3 \mathrm{hr}$ ) であった。

この研究を通じ，実験材料の入手にひとかたならぬお 
便宜を計っていただきました帝人株式会社に謝意を表し ます。

\section{参考 文 献}

1) 阪上正信, 中西 孝; 日本原子力学会誌, 11(6), 332 (1969).

2) Y. Nishiwaki, H. Kawai, H. Morishima, S. IwATA and T. Tsuruta; Rapid Methods for Measuring Radioactivity in the Environment (Proc. Symp. Neuherberg, 1971), p. 267 (1971), IAEA, Vienna.

3) Y. Nishiwaki, T. Tsuruta and K. YAMAZAKI ; J. Nucl. Sci. Technol., 8(3), 162 (1971).

4) 鶴田隆雄; 日本原子力学会誌, $14(9), 462$ (1972).

5) Y. Nishiwaki, T. Tsuruta, T. Ono, K. YAMAZAKI, Y. FUKANO and M. MARUYAMA; Bull. Tokyo Inst. Technol., 83, 131 (1968).

6) H. Hasegawa, M. Matsuo, K. Yamakoshi and K. YAMAZAKI ; Radioisotopes, 17 (9), 419 (1968).

7) 阪上正信；“粒子トラックとその応用”， p. 78 (1973), 南江堂, 東京.

8) L. Tommasino and W.G. Cross; Health Phys., 15, 196 (1968).

9) W.G. Cross and L. Tommasino; Neutron
Dosimetry in Biology and Medicine (Proc. Symp. Neuherberg/Munich, 1972), p. 283 (1972), IAEA, Vienna.

10) W.G. Cross and L. Tommasino; Radiation Effects, 5, 85 (1970).

11) F.J. Congel, T.H. Roberts, D. Dreis, J. Kastner, B.G. Oltman, R. Gold and R.T. ARMANI; Nuclear Instruments and Methods, 100, 247 (1972).

12) Y. Nishiwaki, H. Kawai, H. Morishima, T. KogA and Y. OKADA; Neutron Monitoring for Radiation Protection Purposes (Proc. Symp. Vienna, 1972), p. 117 (1973), IAEA, Vienna.

13) E.T. Agard, R.E. Jervis and K.G. MCNeIll; Health Phys., 21, 625 (1971).

14) S. Pretre; Neutron Monitoring for Radiation Protection Purposes (Proc. Symp. Vienna, 1972), p. 99 (1973), IAEA, Vienna.

15) M. Sohrabi and K. BECKer; ORNL-TM3605 , p. 1 (1971).

16) K. BECKER; Health Phys., 16, 113 (1969).

17) D.R. Stone; Health Phys., 16, 772 (1969).

18) D.R. JoHnson, R.H. BOYETT and K. BeCKER; Health Phys., 18, 424 (1970).

19) J.B. NIDAY; Physical Review, 121, 1471 (1961).

\section{資料頒布のおしらせ}

当会でまとめた下記資料を頒布しております。入手を希望される方は，本会事務局あてにお申し込みくださ い。な招，郵送料は希望者が負担してください。

\section{ICRP に関する学習資料（残り数冊）}

B 5 判, 71 頁, 定価 200 円（郵送料 85 円）

\section{2. 放射線事故等の原因分析と安全対策上の問題点の提起}

A 4 判, 40 頁, 定価 300 円（郵送料 70 円）

3. 放射線の許容線量——その性格と背景—

B 5 判, 93 頁, 定価 500 円 (郵送料 115 円) 